This Journal is available in Telkom University online Journals

Jurnal Manajemen Indonesia

\title{
Emotional Dynamics, Dialogue, And Organizational Innovativeness Of Indonesian Private Tv Stations
}

\author{
D. Tricahyono ${ }^{1}$ \\ ${ }^{1}$ School Economics and Business, Telkom University, Bandung Indonesia
}

\begin{abstract}
Currently, researchers tend to suggest a socially based approach to address the challenge of innovation rather than an economic approach which often fails to address the challenge. This study examines the relationship between emotional dynamics as an independent variable, organizational innovativeness as the dependent variable, and dialogue as a mediator in Indonesian private television broadcasting institutions. Data is collected from 132 respondents who are creative workers at Indonesian private tv stations. Prior to hypotheses testing, this study conducted a factor analysis to check the construct validity of all variables under study. This study used multiple regression analysis to examine direct relationships and two-step hierarchical regression to examine mediating effect. The results show that emotional dynamics have a significant effect on organizational innovativeness and dialogue. The results also show that dialogue partially mediates the relationship between emotional dynamics and organizational innovativeness. This study found that organizational innovativeness can be achieved by those who apply: an open culture, a climate of discussion about new ideas, and a climate of mutual respect. The study also reveals that dialogue is a very important tool that mediates the relationship between open culture and organizational innovativeness. This study proposes that organizational age and the influence of national culture need to be considered for further research on social-based innovation.
\end{abstract}

Keywords - dialogue; emotional dynamics; Indonesian private tv stations; organizational innovativeness

\begin{abstract}
Abstrak
Saat ini, para peneliti cenderung menyarankan pendekatan berbasis sosial untuk menjawab tantangan inovasi dibandingkan pendekatan ekonomi yang seringkali gagal menjawab tantangan tersebut. Penelitian ini mengkaji hubungan antara emotional dynamics sebagai variabel bebas, daya-inovasi organisasi sebagai variabel terikat, dan dialog sebagai mediator di lembaga penyiaran tv swasta Indonesia. Data berasal dari 132 responden yang merupakan para pekerja kreatif di stasiun tv swasta Indonesia. Sebelum menguji hipotesis, dalam penelitian ini dilakukan analisis faktor untuk memeriksa validitas konstruk dari semua variabel yang diteliti. Penelitian ini menggunakan analisis regresi berganda untuk menguji hubungan langsung dan regresi hierarkis dua tahap untuk menguji efek mediasi. Hasil penelitian menunjukkan bahwa emotional dynamics berpengaruh signifikan terhadap daya-inovasi organisasi dan dialog. Hasil penelitian juga menunjukkan bahwa dialog memediasi sebagian hubungan antara emotional dynamics dan daya-inovasi organisasi. Studi ini menemukan bahwa daya-inovasi organisasi dapat dicapai oleh organisasi yang menerapkan: budaya terbuka, iklim diskusi wacana ide-ide baru, dan iklim saling menghormati. Studi ini juga mengungkapkan bahwa dialog adalah alat yang sangat penting yang memediasi hubungan antara budaya keterbukaan dan daya-inovasi organisasi. Penelitian ini mengusulkan agar usia organisasi dan pengaruh budaya nasional perlu dipertimbangkan dalam penelitian lanjutan mengenai inovasi berbasis sosial
\end{abstract}

Kata kunci- dialogue; emotional dynamics; Indonesian private tv stations; organizational innovativeness 


\section{INTRODUCTION}

Many researchers aware that previous studies on organizational innovation were dictated by using an economic approach (Lam, 2005). The economic approach views the world as a static and closed environment. Consequently, because the world is viewed as stable, homogeneous, and linear, many previous research focused on predictable situations and rational decision making. However, in today's volatile, unstable, complex, and ambiguous (VUCA) situation, the economic approach often fails to address the challenges of innovation. Today's organizations must have strong flexibility, which is demonstrated by the mobility, responsiveness, and agility of the organization to quickly adapt to volatile market environment (Anning-Dorson \& Nyamekye, 2020). Dynamic situations require a robust approach that puts cognition, learning, and organizational creativity as the drivers of future innovation research (Lam, 2005; Montreuil, Lauzier, \& Gagnon, 2019). These elements can be found in the microdynamics of organizational change which emphasizes a socially based innovation approach rather than an economic-based approach. Therefore, instead of using economic approach, today's organization is persuaded to implement socialbased innovation in its innovation process.

Socially based innovation emphasizes on human interaction rather than other economic factors, such as technology, capital, fixed assets, etc. (Gallouj, 2002; Moldschl, 2007; Sundbo, 2002, 2003; and Sundbo \& Fuglsang, 2002). As Sundbo and Fuglsang (2002: 9) mentioned: "Innovation contributes to solving some problems as experienced and interpreted by people". Thus, the main goal of social-based innovation is the development of an open society that ensures people to participate in sharing ideas that involve their emotions (Tricahyono, Nilasari, \& Ali, 2008). In socially based innovation, how the organization develop a culture that continuously provides new ideas (because of high-quality interactions) becomes more important than the innovation itself. Lam (2005) suggested that future innovation research should emphasize on understanding the micro dynamics of organizational change, which includes organizational cognition, learning, and creativity. Montreuil et al. (2019) also revealed that there are still limited number of organizations that explore the sources of capabilities to innovate in managerial and organizational perspective.

Scholars believe that organizational innovativeness is an important step for developing an innovative culture in an organization (e.g., Calantone, Cavusgil, \& Zhao, 2002; Hurley \& Hult, 1998; Liu \& Phillips, 2011; Salavou, 2004; Yeung, Ulrich, Nason, \& Von Glinow, 1999; Yousaf, Anser, Tariq, Jawad, Naushad, \& Yousaf, 2020; Wang $\&$ Ahmed, 2004). Organizational innovativeness is an important element in the organizations to develop innovative work behavior to cope with new technologies, new services, and new products (Yousaf et al., 2020). According to Hurley and Hult (1998), organizational innovativeness is a prerequisite for organizational capacity to innovate. Studying organizational innovativeness will contribute to the understanding of early processes of innovation in the organization. This research focuses on organizational innovativeness and tries to identify the internal mechanism of innovation development that comes from organizational culture.

Sundbo (2002) notes that innovation studies with an emphasis on human interaction may provide another perspective to the understanding of innovation process. This study considers emotions in organizations as an antecedent of organizational innovativeness. This emotions in organization represents the least understood and underexploited research theme (Akgün, Keskin, Byrne, \& Aren, 2007; Antonacopoulou \& Gabriel, 2001; Ashkanasy, Härtel, \& Daus, 2002; Basadur \& Gelade, 2006; Huy, 1999, 2002; Lam, 2005; Li, 2019; Rickards, 2003; and Sundbo, 2003). Huy (1999) introduced emotional dynamics as a measure of the level of emotional turmoil in an organization. With emotional dynamics, organizations can increase their acceptance of change and at the same time can effectively mobilize change. The study of Akgün et al. (2007) found that emotional ability at the organizational level has no relationship with innovation. However, in their recent study (Akgün, Keskin, \& Byrne, 2009), they found that four out of the six dimensions of emotional dynamics (i.e., the dynamics of display freedom, dynamics of experiencing, dynamics of reconciliation, and dynamins of identification) influenced product and process innovation, while the other dimensions did not affect product innovation nor process innovation. Recently, Li (2019) found that organizational emotional abilities have a positive effect on employees' innovative behavior. Realizing with these contradictory results, this study introduces dialogue as a mediator of the relationship between emotional dynamics and organizational innovativeness. In a creative environment, dialogue can create the collective intelligence needed to overcome the limited capacity of individual managers to deal with change (Gutíerrez-García \& Recalde, 2016). On the other hand, the element of comfort that comes from collective emotions determines the success of dialogue (Harikkala-Laihinen, Hassett, Raitis, \& Nummela, 2018). Therefore, this study believes that dialogue will stabilize the relationship between emotional dynamics and organizational innovativeness. 
The object of this research is broadcast private tv stations in Indonesia. The broadcast tv industry is characterized as non-technological rather than technological innovation-based (Walker, \& Ferguson, 1998). In this industry, the ability to think out-of-the-box is important because to produce new programs or upgrade existing programs requires creative abilities (Apriyanti, 2007). Management of a tv station can attract talent to work for their tv station. Unfortunately, talent can easily move from one tv station to another. To prevent this, tv station must create comfortable environment that encourages creativity and innovation, where talents can freely collaborate to develop innovative products. At the same time, this climate will encourage the best people to stay working on the tv station and support them to work collectively. Barney, Wright, and Ketchen (2001) suggest that future research should focus on "detailing how strong cultures can create unique resources" (Barney et al., 2001: 635). Therefore, this study focuses on examining how important aspects of organizational climate (as a cultural artifact of an organization) can contribute to organizational innovativeness.

\section{LITERATURE REWIEW}

\section{A. Organizational Innovativeness}

Many previous studies have defined organizational innovativeness as a firm's tendency to engage and support new ideas, novelty, experimentation, and creative processes (Anning-Dorson \& Nyamekye, 2020; Calantone et al., 2002; Yeung et al., 1999); or organizational tendencies toward innovation (Salavou, 2004; Yousaf et al., 2020); or as flexibility and willingness to accept new ways of creating new knowledge (Liu \& Phillips, 2011), or simply organizational openness to new ideas (Hurley \& Hult, 1998). Other scholars tend to use underlying capacity (Francis \& Bessant, 2005), or innovative ability (Wang \& Ahmed, 2004) to express a firm's ability to implement new ideas. It can be concluded that organizational innovativeness is the company's readiness to be involved in innovation process. This readiness may lie in people, technology, culture, or organizational processes. Recently, to understand organizational innovativeness better, Montreuil et al. (2019) proposed three different definitions of organizational innovativeness, which centered on: 1) belief systems and behavior, (2) organizational development processes, and (3) organizational responses to its environment.

This study focuses on emotional issues at the organizational level as an internal mechanism that encourages organizations to be ready for innovation process (i.e., organizational innovativeness). Furthermore, according to Callahan and McCollum (2002), emotion relates to change, and innovation is about the tendency to change.

\section{B. Emotional Dynamics}

Huy $(1999,2002)$ emphasizes that at organizational level, it is important to understand of how emotions can influence member's interpretation and behavior. Antonacopoulou and Gabriel (2001) observed that emotions as a crucial dimension of individual and organizational that influence everyday processes in an organization. Da Camara, Dulewicz, and Higgs (2015: 325) define organizational emotional intelligence (OEI) as "a set of organizational competencies and capabilities which allow organizations to be aware of members' emotions and manage them effectively; and, therefore, supports and facilitates the expression of individual emotional intelligence among members."

Huy (1999) developed a framework of emotional dynamics (see Fig. 1) as a messo level that bridges between emotional intelligence at individual level (Goleman, 1995; Salovey \& Mayer, 1990) and emotional ability at organizational level (Schein, 1992). According to Huy (1999), individuals and organizations that carry out emotional dynamics will have opportunity to be succeeded in dealing with dynamics of radical change. Furthermore, Huy (2002) noted that emotional dynamic lies at internal tacit capabilities level of an organization, namely emotional energy. Huy (1999) suggests six dimensions of emotional dynamics, namely:

1) Dynamic of encouragement refers to ability of an organization to provide hope among all its members.

2) Dynamic of display freedom refers to organization's ability to sustain genuine emotions that can be legitimately displayed (and felt) within the organization.

3) Dynamic of playfulness demonstrates organization's ability to create an environment that encourages experimentation without fear of making mistakes.

4) Dynamic of experiencing refers to an organization's ability to recognize, accept, and internalize a wide range of emotions, and act on a deep level of understanding.

5) Dynamic of reconciliation is organization's ability to bring together two seemingly opposing values in which people have strong feelings; and 
6) Dynamic of identification is a collective behavior that show a strong attachment of organizational members to central organization's characteristics which are shown as core values, beliefs, myths, leaders, or other factors that are considered very important for individuals or groups.

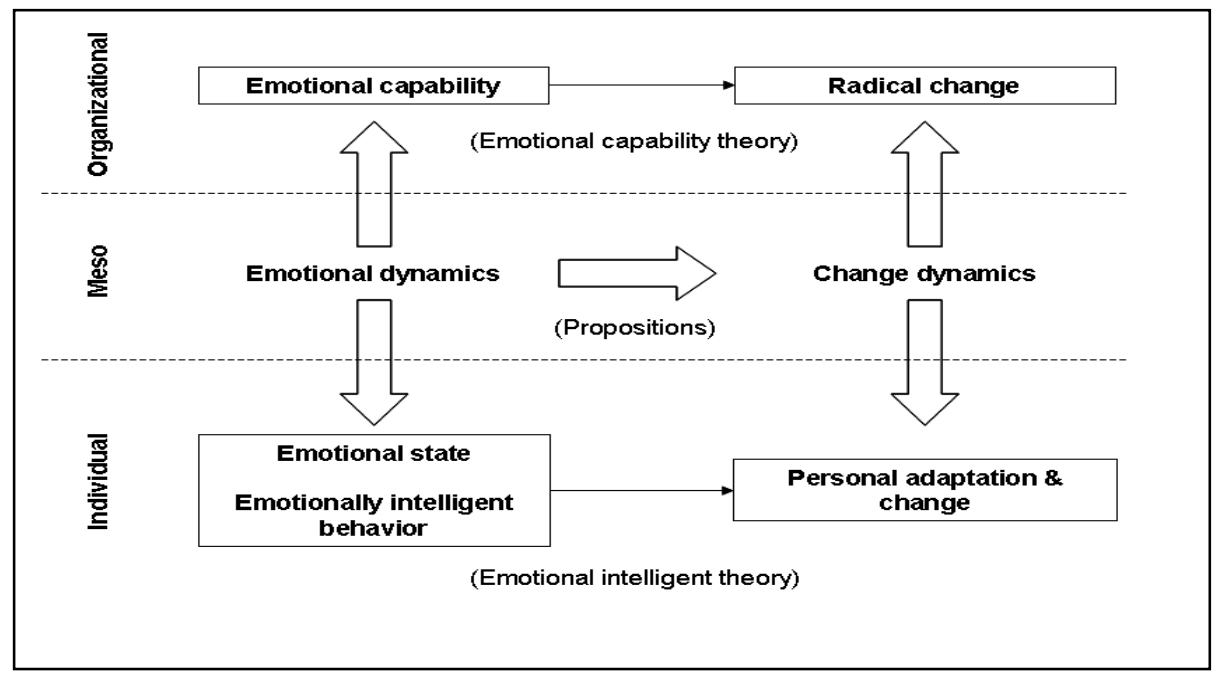

Figure. 1 Emotions Dynamics (Source: Huy (1999: 326)

Von Koskull, Strandvik, and Tronvoll (2016) found that emotions provide energy and direction to service innovation process. Menges and Bruch (2009) revealed that collective emotional intelligence in organization (i.e., emotional dynamics) positively relates to operational, financial, and innovation performance. According to Huy (1999), to jump from individual emotional intelligence into organizational emotional capabilities, organization must integrate all individual emotional intelligences, harmoniously.

\section{Dialogue}

Scholars understand dialogue as how a group of people think together generatively and creatively to achieve common understanding and insight to achieve conceptual breakthroughs (Bokeno, 2007; Issacs, 1993; Schein, 1993; Senge, 1990). Dialogue and discussion are different. According to Prewitt (2011), discussion is a confrontational conversation (sometimes one-way communication) aim at forcing arguments, convincing others, or winning verbal battle. On the other hand, dialogue is a multi-way communication process that aims to achieve commitment because of developing a higher level of understanding of all participants' intentions and experiences (Harikkala-Laihinen et al., 2018). Dialogue is about listening with deep empathy, taking on the meanings and intentions of others, challenging assumptions, seeing connections, creating shared meaning, and achieving conceptual breakthrough (Ayuso, Rodríguez, \& Ricart, 2006; Jabri, 2004; Prewitt, 2011; Senge, 1990).

Chiva, Alegre, and Lapiedra (2007: 228) define dialogue as "an ongoing collective inquiry into the processes, assumptions, and certainties that shape everyday experience." Collectively, all participants get an agreement on a shared meaning, not just get an agreement on a single meaning. The dialogue process is not an easy task. This should begin with the process of classifying the thoughts of all participants in relation to their intentions and experiences (Gutíerrez-García \& Recalde, 2016). After each member's reasons are understood, the discourse will move slowly and systematically to reach a consensus of meaning. Under the condition of high uncertainty and high task interdependence, willingness to accept differences of all participants' reasons can lead to greater levels of achievement (Jabri, 2004). The quality of dialogue is determined by the quality of interaction between participants (Issac, 1999). According to Liu, Chua, and Stahl (2010), interaction quality is defined as perception of clarity, responsiveness, and comfort in interactions. In this case, organization must create an atmosphere in which positive emotions arise (Harikkala-Laihinen et al., 2018). Choi (2014) noted that dialogue requires reason and emotion. "Dialogue can be influenced by emotional energy, spontaneity, shared interests, and rational reasons" (Ballantyne, 2004: 120). 


\section{The Framework of Study}

Based on literature review, this study develops a framework for thinking that can be seen in Fig. 2. Following Hurley and Hult (1998), organizational innovativeness is influenced by cultural characteristics. Thus, the right mix of organizational culture will support organizational innovativeness (Hurley \& Hult, 1998). According to Mackie, Devos, \& Smith (2000) organizational emotions come from several causes, namely: common interpretation, collective experience, identity, and organizational culture. Organizational culture guides collective emotions and provides emotional experiences with employees (Huy, 2012). Thus, this study assumes that dynamics of emotions as collective emotions of organizations are part of cultural characteristics.

Previous studies have shown that emotional dynamics influence organizational innovativeness (e.g., Akgün, et al., 2009; Li, 2019; Menges \& Bruch, 2009; Von Koskull et al., 2016). Innovation is about organizational tendency to change which is influenced by positive emotions (Callahan \& McCollum, 2002; Harikkala-Laihinen et al., 2018). However, previous research has not come to solid conclusions regarding the relationship. Some dimensions of emotional dynamics have been shown to influence some forms of innovation, but others have not. To obtain a more robust model, this study introduces dialogue as a mediator of the relationship between emotional dynamics and organizational innovativeness. As we know, emotions (at individual or organizational level) are unstable. To ensure that organizational emotions have a positive effect on innovation, organizations must establish internal mechanisms to stabilize dynamic emotions. This study proposes dialogue as an internal mechanism to stabilize emotional conditions in an organization. This framework creates four main hypotheses:

H1: The six dimensions of emotional dynamics positively influence organizational innovativeness,

H2: The six dimensions of emotional dynamics positively influence dialogue,

H3: Dialogue positively influences organizational innovativeness, and

H4: Dialogue mediates the relationship between six dimensions of emotional dynamics and organizational innovativeness.

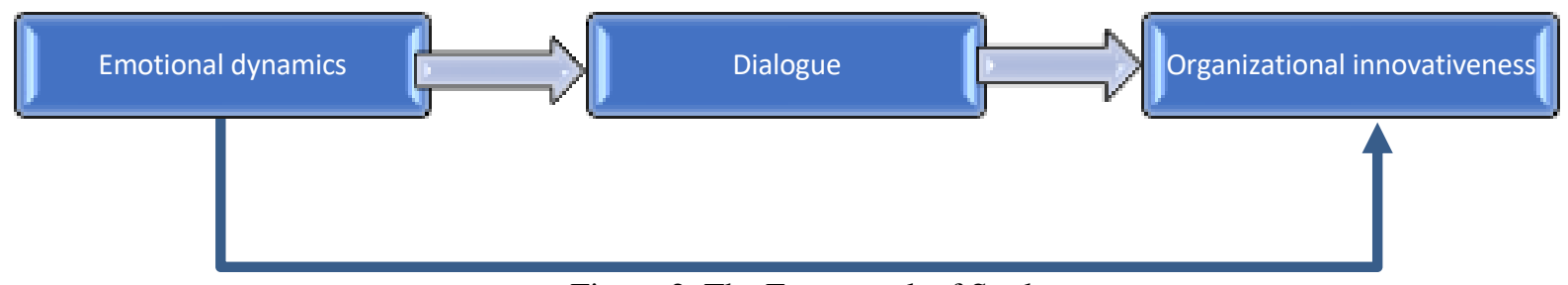

Figure 2. The Framework of Study

\section{RESEARCH METHODOLOGY}

\section{A. Data Collection Procedures}

As quantitative research, this research applies a cross sectional data survey for data collection. This study implemented a census of all members of tv associations in Indonesia, namely: ATVSI (Indonesian Private TV Association), ATVLI (Indonesian Local TV Association), ATVJI (Indonesian TV Network Association), and ATVNI (Indonesian National TV Association). This study distributed questionnaires to 193 private tv stations in all big cities in Indonesia in the January-April 2019 period via email. This questionnaire is addressed to creative people (e.g., executive producers, editors, art directors, directors of photography, script development executives, etc.) at a tv station, because of their role as engines of creativity and innovation. By attaching a letter from the leadership of the tv associations, 154 questionnaires were returned from all targeted respondents (193 tv stations), but only 132 were valid and are being processed for analysis (response rate 68.4\%). Table 1 shows the profiles of the respondents, while Table-2 shows the profiles of tv stations.

Because the respondents came from 11 national private tv stations and 121 local tv stations, this research was conducted with a test of difference. The results showed that all the t-values of variables under study were statistically significant (all 2-tailed sig. values were above 0.05). It can be concluded that there is no statistically significant difference between national and local private tv stations. Therefore, there is no serious response bias between the two groups of respondents in this study. 
Table 1. Profile of the TV Stations' Creative People

\begin{tabular}{llcc}
\hline Variable & & Frequency & $\%$ \\
\hline Gender & Male & 90 & 68.2 \\
& Female & 42 & 31.8 \\
\hline Educational Level & High School & 15 & 11.4 \\
& College & 13 & 9.8 \\
& Bachelor Degree & 92 & 69.7 \\
& Master Degree & 12 & 9.1 \\
\hline Educational Background & Art & 14 & 10.6 \\
& IT \& Engineering & 18 & 13.6 \\
& Communication & 39 & 29.5 \\
& Management & 30 & 22.7 \\
\hline Age & Others & 31 & 23.5 \\
\hline Job Tenure & $20-40$ & 97 & 73.5 \\
& $41-60$ & 34 & 25.7 \\
\hline Training in TV Broadcast & Above 60 & 1 & .8 \\
\hline Is this the first company? & Less than 10 years $*)$ & 85 & 64.4 \\
& 10 years and more & 47 & 35.6 \\
\hline Is your previous job in TV industry? & No & 30 & 22.7 \\
& Yes & 102 & 77.3 \\
\hline Note: & No & 100 & 75.8 \\
& Yes & 32 & 24.2 \\
\hline
\end{tabular}

Note : *) Average job tenure is 5.15 years

Table 2. Profile of TV Stations

\begin{tabular}{llrr}
\hline Variable & & Frequency & $\%$ \\
\hline Broadcast Coverage & Local & 121 & 91.7 \\
& National & 11 & 8.3 \\
\hline Targeted Segment & Broad Segment of TV Program & 121 & 91.7 \\
& Specific Segment of TV Program & 11 & 8.3 \\
\hline Number of full-times employees *) & $19-42$ people & 45 & 34.8 \\
& $43-60$ people & 45 & 34.1 \\
& More than 60 people & 37 & 31.1 \\
\hline Company Age (in years) $* *)$ & 2-15 years & 67 & 50.8 \\
& More than 16 years & 65 & 49.2 \\
\hline Company Ownership & Local & 98 & 74.2 \\
& National & 18 & 13.6 \\
& Joint with local partner & 12 & 9.1 \\
& Joint with foreign partner & 4 & 3.0 \\
\hline Own a production house? & Yes & 87 & 65.9 \\
& No & 45 & 34.1 \\
\hline Total Percentage of in-house production & Below 50\% & 71 & 53.8 \\
& $50 \%$ to 80\% & 52 & 39.4 \\
& More than 80\% & 9 & 6.8 \\
\hline
\end{tabular}

Note: *) Anerage number of full time employees is $156.59, * *)$ Average company ages is 6.3 years

\section{B. Measurements}

The questionnaire consists of two large sections: general questions about profile of respondents and their tv stations, and the Likert-type questions about the variables being studied (i.e., organizational innovativeness, 
emotional dynamics, and dialogue). The first part consists of 20 open-ended questions and the second part consists of 38 closed questions related to the three variables involved.

In social sciences, it is common to use factor analysis in analyzing construct validity of predefined constructs by testing dimensions among items (DiStefano \& Hess, 2005; Knekta, Runyon, \& Eddy, 2019; Mulaik, 1987). According to DiStefano and Hess (2005), confirmatory factor analysis (CFA) is widely used to evaluate a construct that developed first and was driven by a theoretical basis. Therefore, to test the construct validity of all variables, this study applies CFA and continues with reliability analysis by using Cronbach Alpha.

Using the single construct of Hurley and Hult (1998) and following the study of Katrinli, Atabay, Gunay, Guneri, and Aktan (2009), organizational innovativeness was measured by a total of six items. This measurement uses a five-points Likert scale ranging from "Never" = "1" to "All the time" = "5." One example of an item for organizational innovativeness is: "Management is actively seeking innovative ideas." The factor analysis process confirmed all six items. Cronbach's score for organizational innovativeness is 0.90 which indicates reliable since the value is more than 0.70 (Hair et al., 2006; Sekaran \& Bougie, 2010).

Emotional dynamics was measured by using 27 items from Akgün et al. (2008), who developed a measurement of emotional dynamics from Huy's (1999) work. All six dimensions were measured by using a five-points Likert scale ranging from "Strongly Disagree" (1) to "Strongly Agree" (5). Initially, emotional dynamics (ED) had 27 items in six different dimensions. However, after the factor analysis, only five factors remained with a total of 24 items, namely: dynamics of reconciliation, dynamics of display freedom, dynamics of identification, dynamics of encouragement, and dynamics of experiencing. Dynamics of playfulness merged into dynamics of display freedom dimension. Respondents may believe that ability to experiment and tolerate mistakes during any course of action (i.e., dynamics of playfulness) is part of organization's ability to honestly present a variety of authentic emotions within an organization (i.e., dynamics of display freedom). Factor analysis confirmed all 24 items (in five dimensions). Cronbach's score for emotional dynamics is 0.83 which indicates reliable because the value is more than 0.70 (Hair et al., 2006; Sekaran \& Bougie, 2010).

Dialogue (DIA) was measured by implementing five-items construct adapted from Chiva et al. (2007). This study uses five Likert scales ranging from " $1 "=$ strongly disagree to " $5 "=$ strongly agree. The factor analysis dropped one item (i.e., "There is an information management system from outside the company") because the communality score was low and confirmed the other four items. Cronbach score was 0.84 which indicates reliable because the score is more than 0.70 (Hair et al., 2006; Sekaran \& Bougie, 2010).

\section{Hypotheses Testing}

This study uses regression analysis to test all direct hypotheses. Regression analysis is best done when each independent variable is strongly correlated with the dependent variable but not correlated with other independent variables (Tabachnick \& Fidell, 2007). To test the effect of mediators, this study implemented the Baron and Kenny (1986) protocol. According to Baron and Kenny (1996), the mediation effect only exists if independent variable has a significant effect on both dependent variable and mediator, and mediator has a significant effect on dependent variable. Furthermore, this study used a two-steps hierarchical regression analysis to examine the effects of mediator. The first step is for independent variable (Model-1) and the second step is for mediating variable (Model-2). If the results of Model-2 shows that the Standard Beta is reduced and the relationship between independent variable and dependent variable becomes insignificant then there is a full mediation effect. However, if the results of Model-2 show that Standardized Beta is reduced and the relationship between independent variable and dependent variable is still significant, then there is a partial mediating effect.

Hair et al. (2006) stated that the correlation coefficient (r) $>0.90$ was considered a very strong association, $0.71<\mathrm{r}<0.90$ as a high association, $0.41<\mathrm{r}<0.70$ as a moderate association, $0.21<\mathrm{r}<0.40$ as a small but definite relationship, and $\mathrm{r}<0.20$ as a small and negligible relationship. Descriptive statistics and bivariate correlations can be seen in Table-3. Since all dimensions of emotional dynamics (ED) have $r$ more than 0.50 to 0.71 with respect to organizational innovativeness, the independent variable (i.e., ED) is positively and moderately to high correlated with the dependent variable (i.e., OI). Inter-correlation between all ED dimensions was found to be significant with $\mathrm{r}$ ranging from small to moderate association. Intercorrelation between all dimensions of ED to dialogue showed a small to moderate association ( $\mathrm{r}$ ranging from 0.43 to 0.64 at $\mathrm{p}<.01$ ), except for dynamics of display freedom (DDF) and dialog (DIA) which showed high association. $(\mathrm{r}=.74, \mathrm{p}<.01)$. In conclusion, all hypotheses regarding the relationship between the dimensions of ED and all other variables are acceptable. 
Table 3. Pearson correlation matrix of all the investigating variables $(n=132)+$

\begin{tabular}{cccccccccc}
\hline & Mean & SD & DRN & DDF & DIN & DEN & DEX & DIA & OI \\
\hline DRN & 3.37 & .70 & 1 & & & & & & \\
DDF & 3.41 & .78 & $0.66^{* *}$ & 1 & & & & \\
DIN & 3.54 & .76 & $0.61^{* *}$ & $0.56^{* *}$ & 1 & & & \\
DEN & 3.23 & .70 & $0.41^{* *}$ & $0,43^{* *}$ & $0.32^{* *}$ & 1 & & \\
DEX & 3.73 & .81 & $0.55^{* *}$ & $0.51^{* *}$ & $0.52^{* *}$ & $0.37 * *$ & 1 & & \\
DIA & 4.06 & .70 & $0.60^{* *}$ & $0.74^{* *}$ & $0.48^{* *}$ & $0.41^{* *}$ & $0.62^{* *}$ & 1 & \\
OI & 3.74 & .90 & $0.67^{* *}$ & $0.71^{* *}$ & $0.56^{* *}$ & $0.50^{* *}$ & $0.54^{* *}$ & $0.71^{* *}$ & 1 \\
\hline
\end{tabular}

$* *$ Correlation is significant at the 0.01 level (2-tailed), * Correlation is significant at the 0.05 level (2-tailed)

\section{RESUlt AND DisCUSSION}

\section{A. Result}

\section{a) Hypotheses Testing: Direct Relationships}

The direct relationships comprise of relationships between ED and OI (Table 4), ED and DIA (Table 5), and DIA and OI (Table 6). Table 4 shows that among five dimensions of ED, three dimensions have a significant effect on OI, namely: dynamics of encouragement $(\beta=.171, p<.01)$, dynamics of display freedom $(\beta=.367, p<.01)$, and dynamics of reconciliation $(\beta=.238, p<.01)$. These three dimensions explained $62 \%$ of OI's variances. Compares to Akgün et al.'s (2009) study, this study has higher $\mathrm{R}^{2}$ (Akgün et al.'s $\mathrm{R}^{2}$ was 0.33 for product innovation and 0.49 for process innovation). Thus, in this study organizational innovativeness is strongly explained by emotional dynamics.

Table 5 shows that among six dimensions of ED, only two dimensions (namely dynamic of display freedom $[\beta=.523, p<.01]$ and dynamics of experiencing $[\beta=.304, p<.01]$ ) significantly affect dialogue. $\mathrm{R}^{2}$ shows that these two dimensions explain $64 \%$ of dialogue variance. This study shows that dialogue will success if private tv stations show a climate where all members have freedom to express their emotions legally. Dialogue requires social interaction between participants. Social interactions that include initiating relationships, providing emotional support to others, and managing conflict depend on people's ability to manage and regulate emotions in themselves and others (Harikkala-Laihinen, et al., 2018; Yip \& Martin, 2006). In substance, this capability is about how organizations can reduce power distance and differences among their dialogue communities (Rose-Andersen \& Allen, 2008) to increase openness and conditions of psychological security.

Table 6 shows that dialogue $(\beta=.713, p<.01)$ has a significant effect on organizational Innovativeness. The results showed that process of how a group of people think together generatively and creatively to achieve common understanding and insight had a significant effect on organizational innovativeness (with $\mathrm{R}^{2}=51 \%$ ). Since we agree that organizational innovativeness is how organizations develop their willingness to change (Calantone et al., 2002); consequently, dialogue is an important aspect to encourage willingness to change in an organization.

Table 4. Multiple Regression Results: ED and OI

\begin{tabular}{lc}
\hline \multicolumn{2}{c}{ Dependent variable: $\begin{array}{r}\text { Organizational Innovativeness } \\
\text { Standardized Beta }\end{array}$} \\
\hline Independent Variable: & \\
Emotional Dynamic & $.171^{* *}$ \\
Dynamic of encouragement & $.367 * *$ \\
Dynamic of display freedom & .103 \\
Dynamic of experiencing & $.238^{* *}$ \\
Dynamic of reconciliation & .106 \\
$\quad$ Dynamic of identification & .621 \\
\hline $\mathrm{R}^{2}$ & .606 \\
$\mathrm{R}^{2}$ Adjusted &
\end{tabular}


Table 5. Multiple Regression Result: ED and DIA

\begin{tabular}{lc}
\hline & $\begin{array}{r}\text { Dependent variable: Dialogue } \\
\text { Standardized Beta }\end{array}$ \\
\hline Independent Variable: & \\
Emotional Dynamic & .049 \\
$\quad$ Dynamic of encouragement & $.523^{* *}$ \\
Dynamic of display freedom & $.304^{* *}$ \\
Dynamic of experiencing & .098 \\
Dynamic of reconciliation & .042 \\
$\quad$ Dynamic of identification & .636 \\
\hline $\mathrm{R}^{2}$ & .621 \\
$\mathrm{R}^{2}$ Adjusted
\end{tabular}

Note: Significant level $* * \mathrm{p}<.01, * \mathrm{p}<.05$

Table 6. Multiple Regression Results: DIA and OI

\begin{tabular}{|c|c|}
\hline & $\begin{array}{l}\text { ional innovativeness } \\
\text { Standardized Beta }\end{array}$ \\
\hline $\begin{array}{l}\text { Independent Variable: } \\
\text { Dialogue }\end{array}$ & $.713 * *$ \\
\hline $\mathrm{R}^{2}$ & .636 \\
\hline $\mathrm{R}^{2}$ Adjusted & .621 \\
\hline
\end{tabular}

\section{b) Hypothesis Testing : Mediating Relationship}

The result of direct relationship testing revealed that only one possible opportunity that dialogue can become a mediator, namely in the relationship between dynamics of display freedom with organizational innovativeness. Table 7 shows that dialogue partially mediated the relationship between dynamics of display freedom and organizational innovativeness since beta score decreased from 0.709 (Model-1) to 0.400 (Model-2) but the relationship was still significant.

Table 7 Hierarchical Regression Analysis Results: The Mediator Effect of Dialogue

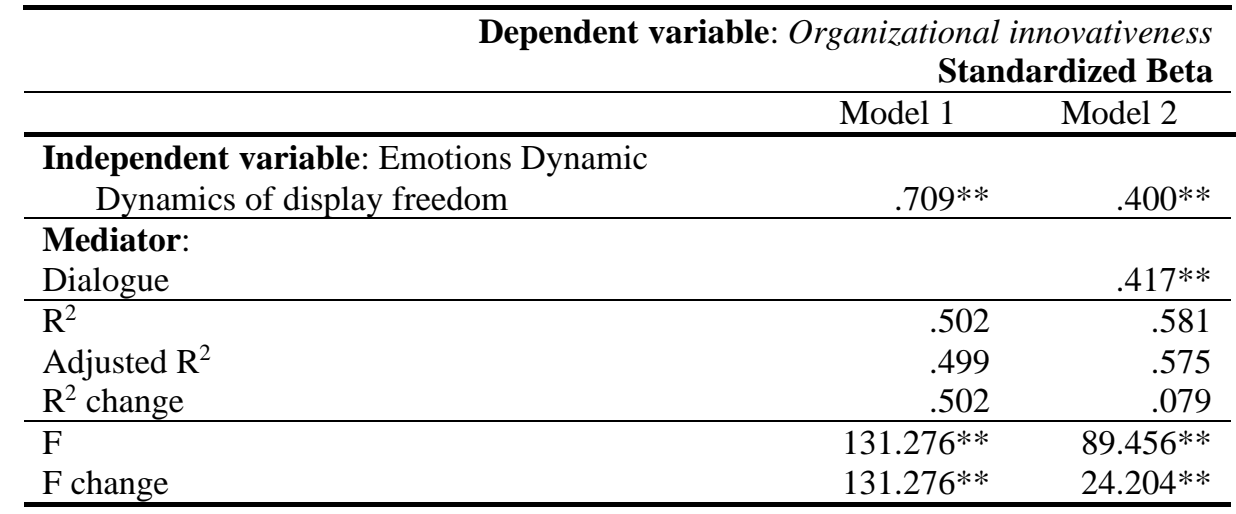

Note: Significant levels $* * p<.01, * \mathrm{p}<.05$

\section{B. Discussion}

\section{a) The Relationships Between Emotional Dynamics and Organizational Innovativeness}

This study found that organization's ability to instill hope among all its members (dynamics of encouragement); organizational ability to facilitate and support a variety of authentic emotions (dynamics of display freedom); and 
organization's ability to reconcile two seemingly opposite values (dynamics of reconciliation) has positive effects on organizational innovativeness of Indonesian private tv stations. Compares to Akgün et al.'s (2009) study, this study found the same results on dynamic of playfulness and dynamic of identification which significantly affect organizational innovativeness. Both studies also found that dynamic of playfulness and dynamic of identification did not affect organizational innovativeness. However, these two studies found contradictory results on two other dimensions: dynamic of reconciliation and dynamic of experiencing. These differences can be explained by looking on research objects. This study used a single industry setting (i.e., private tv broadcasting industry) and a single departmental population type (i.e., creative department), whereas Akgün et al.'s study used a multi-industry setting and all types of line manager populations. Furthermore, the study of Akgün et al. (2009) constructed innovativeness as product and process innovativeness, while this study assumed organizational innovativeness as a holistic construct.

When change must be implemented and organizations must prepare for change, this study finds that private Indonesia tv stations must rely on their three emotional capabilities. First, ability of an organization to provide hope among all members (Huy, 1999). This ability requires managers to generate hope, enthusiasm, and satisfaction among employees, so that they can express their feelings without fear or embarrassment. Second, organization's ability to sustain genuine emotions that can be legitimately displayed (and felt) within the organization. It is about how an organization tolerates mistakes made by its employees who take new initiatives. It is also about how the organization supports a work environment so that employees can explore new ideas without fear of failure, and at the same time, enhance an atmosphere that encourages employees to communicate their deep emotions. Finally, their ability to unite two seemingly opposing values that make people feel valued (Huy, 1999). It is about how employees understand and respect the feelings of others (whether they have direct experience or not) while maintaining their personal feelings. With this ability, members of the organization will have a sense of closeness that leads to emotional bonds as a basic level of security and comfort. This finding is in line with the research of Akgün et al. (2009), that under uncertain conditions, support for risk taking and fault tolerance can stimulate innovative behavior in an organization (Akgün et al., 2009).

This study revealed that other two dimensions (i.e., dynamics of experience and dynamics of identification) have no significant effect on organizational innovativeness. It appears that organization's ability to identify, understand, and internalize other emotions does not affect organizational innovativeness. In addition, organization's ability to develop strong collective behavior also does not affect organizational innovativeness. In the Indonesian context, this result is acceptable, because Indonesian protects harmonious social appearances and minimizes open expressions of social and personal conflict (Kartodirjo, 1991). Thus, balance of harmony in an organization is highly appreciated among Indonesian employees. This result can be explained because most of tv stations in Indonesia are classified as young companies. According to Huy (1999), emotional bond between employees and their organizational identity (or reputation) requires more time and resources to increase their acceptance of the proposed change. Huy also mentioned that quality of organizational efforts to identify, accept, internalize, and apply various emotions (i.e., dynamics of experiencing) requires training and coaching efforts from the organization. Again, the young age of Indonesian private TV stations limits them from providing an appropriate level of training and coaching to their employees.

\section{b) The Relationships Between Emotional Dynamics and Dialogue}

In this study, dialogue was also found to be affected by caring for one another to identify, accept, internalize, and act on the level of deep understanding of other person's feelings (i.e., dynamic of experiencing). These findings emphasize that successful dialogue requires an emotional bond that increases trust among the participants. As a result, trust makes people think that they are emotionally integrated (Gebert, Boerner, \& Lanwehr, 2003). If employees trust their managers, they will usually show high levels of job satisfaction, openness, and selfconfidence (Dull, 2010). Thus, dialogue will be achieved if private Indonesian tv stations care and pay attention to the emotions of their employees to increase their emotional bond.

Interestingly, this study found that dialogue was not influence by dynamics of encouragement, dynamics of reconciliation, and dynamics of identification. Two possible answers may explain why there are insignificant results. First, lies in Indonesian culture and character. According to Kartodirjo (1991), Indonesian likes harmonious relationships in social interactions. They will minimize open expression of social and personal conflicts. Cultures such as those in western countries, where people can express personal identity and value personal excellence, rarely appear in everyday life in many Indonesians. As a collectivist culture (Hofstede, 1997), Indonesian feel comfortable as members of a group (as 'we') rather than as individuals (as 'me'). Furthermore, in Indonesia, if a person takes the initiative too strongly (initiative is the keyword for encouragement/identification), he will be 
judged as 'arrogant' (unless he has strong support from other employees) and dialogue will not occur (Koentjaraningrat, 2002). Individuals who are 'arrogant' will spoil the peaceful atmosphere. Indonesian do not want to face unpleasant facts and try to avoid personal responsibility (Dusik \& Kappiantari, 2010). Thus, dialogue will stop if no one wants to be in charge of controlling the issue, for example simply because of the absence of a senior official. Second, insignificant results may come again from the young age of most Indonesian tv stations. Organization needs time, resources, and efforts to develop emotional bonding between employees and organization (Huy, 1999). Furthermore, this study finds that employees' deep relationship with organizational reputation (i.e., dynamics of identification) does not encourage dialogue. Again, this can be explained by the young age (predominantly less than 15 years of operation) of private Indonesian tv stations and the short tenure of managers (most have worked less than six years at the tv station).

\section{c) The Relationships Between Dialogue and Organizational Innovativeness}

Chiva et al. (2007) defines dialogue as the ongoing collective inquiry into the processes, assumptions, and results that will shape everyday experience. This collective inquiry process is initiated by feelings of dissatisfaction based on previous similar experiences (Elkjaer, 2004). Elkjaer added that this inquiry would not stop until uncertainty that inquirer thought moved to a problem statement. In other words, dialogue will stop until everybody agrees and accept all situations which is reflected by a clear problem statement. Instead of finding solutions to identified problems, dialogue focuses on relational inferences that come from understanding each other's emotions and experiences (Heath, Pearce, Shotter, Taylor, Kersten, Zorn, Roper, Motion, \& Deetz, 2006).

Jacobs and Heracleous (2005) as well as Gutíerrez-García and Recalde (2016) noted that reflective dialogue can lead to change if strategic innovation is critical to a firm's survival. Qualitatively, Ayuso et al. (2006) found that stakeholder dialogue and integration of stakeholder knowledge contribute to a firm's dynamic capability for sustainable innovation. This study provides empirical evidence that dialogue has a strong and positive relationship with organizational innovativeness. Good dialogue also avoids the emergence of identity-based conflicts (McDonald, 2011) or interpersonal conflicts (Chen, 2006, De Dreu, 2006; Jehn, 1995), which are known as negative aspects of innovation. Thus, this study concludes that when private Indonesian tv stations encourage dialogue among their members during their interactions with the internal and external environment, they will have a high degree of openness to new ideas (i.e., organizational innovativeness).

\section{d) The Mediating Effect of Dialogue}

This study found that dialogue partially mediates the relationship between dynamics of display freedom and organizational innovativeness in Indonesian private tv stations. In other words, the ability of private Indonesian tv stations in encouraging and supporting authentic emotions that can be legitimately displayed and felt in organizations can increase their organizational innovativeness directly or indirectly through dialogue.

Dialogue requires social interaction between participants. Social interactions, that include initiating relationships, providing emotional support to others, and managing conflict, depend on people's ability to manage and regulate emotions in themselves and others (Yip \& Martin, 2006). Since dialogue is rooted in social interactions among different participants, disagreements and conflicts will take part in it. Fortunately, conflict provides opportunities for learning (Argyris \& Schon, 1978). Good dialogue is not a conflict-free dialogue (Issac, 1993). However, not every conflict leads to organizational learning (Brundin \& Melin, 2011), of which dialogue is a part. Identity-based conflict can hinder organizational learning (McDonald, 2011) because people prefer to use defensive reasoning (Brown \& Starkey, 2000). For example, debates between functions in an organization will not reach mutual agreement if each party sticks to its functional point of view. Huy (2002: C3) describes when goals are not achieved, people become frustrated and show agitated emotions such as fear, anger, and discomfort. Furthermore, Von Koskull et al. (2016) found that anxiety is a type of emotion that primarily drives service innovation. However, since dialogue is a collective thought and inquiry (Issacs, 1993), it mitigates this negative effect. According to Schein (1993), dialogue is a critical process for building mutual understanding by letting one see the hidden meaning of words. Furthermore, Schein (1993) adds that a clearer meaning and a set of shared meanings as a sign of a situation of mutual understanding that can be achieved by letting go of disagreements. In this case, if private Indonesian tv stations want to encourage dialogue, they can induce task-based conflicts (e.g., differences in viewpoints, ideas, and opinions), but must prohibit identity-based conflicts. For example, by developing and implementing a code of ethics that controls the behavior of employees in the organization. 


\section{CONCLUSION AND RECOMMENDATION}

This research demonstrates that the human side of organization is very crucial for organizational innovativeness. This study shows that emotional dynamics significantly affect organizational innovativeness. Three out of five dimensions of emotional dynamics, namely: dynamics of display freedom, dynamics of reconciliation, and dynamics of encouragement, significantly and positively influence organizational innovativeness. Organizational innovativeness can be implemented properly if the organization develops: (1) a culture of openness that allows all members to express their feelings and opinions without feeling fear to make mistake or being embarrassed; (2) an organizational climate that allows members to communicate freely about the exploration of new ideas; and (3) an organizational climate that allow its members to respect each other to build strong emotional connection between them. This study also reveals that only two of five dimensions of emotional dynamics, namely the dynamics of display freedom and dynamics of experiencing have significant relationship with dialogue. Dialogue requires social interaction and an emotional bond that increases trust between participants. Social interactions consist of several elements, such as initiating relationships, providing emotional support to others, and managing conflict. Whereas emotional bond can be formed through the development of a sense of caring among members of the organization.

Furthermore, this study shows that dialogue influences organizational innovativeness. Good dialogue in organization leads to organizational innovative behavior. Good dialogue supports psychological security that create enthusiasm and excitement for all members of the organization to take a risk in doing their work. Thus, dialogue can be achieved if organization develops the emotional bond among their members. This study also found that not all dimensions of emotional dynamics affect organizational innovativeness and dialogue. This condition can be explained by the presence of other factors, such as national culture. In the context of this study, national culture of Indonesia can be described by collectivity and harmonization above individual interests. Another factor that can explain this condition probably come from the age of organization.

This study finds that dialogue partially mediates the relationship between the dynamics of display freedom and organizational innovativeness. A culture of openness that allows all members to express their feelings and opinions freely directly affect organizational innovativeness and indirectly through dialogue. This culture of openness is fragile and leads to negative conflict or positive conflict. Dialogue can be used to block negative conflict and make organizational learning happen. In conclusion, the process of synthesizing emotions by managing conflict will encourage good dialogue and in turn lead to higher level of organizational innovativeness.

This study has limitations in several areas. First, all respondents come from one industry, namely the tv broadcasting industry. Further research can be implemented across multiple industries or multi-industry. Second, dialogue is not the only factors that can be used to stabilize the relationship between emotional dynamics and organizational innovativeness. Future research can examine other variables that have the same role as dialogue, for example: teamwork, communication with internal and external stakeholders, willingness to share, openmindedness, etc. Third, role of leaders is very important to encourage a pleasant environment that turn collective emotions into energy of organizational innovation. Thus, further research should take leadership as an important variable.

The findings of this study also contribute to the idea that national culture (in this case is Indonesian culture) influences organizational dynamics. Thus, managing organizational climate and culture cannot be separated from the national culture (see Ulijn \& Weggeman, 2001). Therefore, this study recommends future research in socially based innovation study to involve national culture as a moderating variable.

\section{REFERENCES}

Akgün, A. E., Keskin, H., Byrne, J. C., \& Aren, S. (2007). Emotional and learning capability and their impact on product innovativeness and firm performance. Technovation, 27, 501-513.

Akgün, A. E., Keskin, H., \& Byrne, J. C. (2008). The moderating role of environmental dynamism between firm emotional capability and performance. Journal of Organizational Change, 21(2), 230-252.

Akgün, A. E., Keskin, H., \& Byrne, J. C. (2009). Organizational emotional capability, product and process innovation, and firm performance: An empirical analysis. Journal of Engineering and Technology Management, 26, 103-130. 
Anning-Dorson, T. \& Nyamekye, M. B. (2020). Be flexible: turning innovativeness into competitive advantage in hospitality firms. International Journal of Contemporary Hospitality Management, 32(2), 605-624.

Antonacopoulou, E. P., \& Gabriel, Y. (2001). Emotion, learning and organizational change. Towards an integration of psychoanalytic and other perspectives. Journal of Organizational Change Management, 14(5), 435-451.

Apriyanti, A., (2007). Profil Kreatifitas Adaptor-Innovator pada Produser Program Acara Hiburan Televisi di Jakarta. Unpublished undergraduate thesis, Universitas Kristen Atma Jaya, Jakarta, Indonesia.

Argyris, C., \& Schön, D. (1978). Organizational Learning: A Theory of Action Perspective. Reading, Mass: Addison-Wesley.

Ashkanasy, N. M. (2003). Emotions in organisations: a multi-level perspective. Organizational Behavior and Strategy Research, 2, 9-54.

Ashkanasy, N. M., Härtel, C. E. J., \& Daus, C. S. (2002). Advances in organizational behavior: diversity and emotions. Journal of Management, 28, 307-338.

Ayuso, S., Rodríguez, M. A., \& Ricart, J. E. (2006). Responsible competitiveness at the "micro" level of the firm. Using stakeholder dialogue as a source for new ideas: a dynamic capability underlying sustainable innovation. Corporate Governance, 6 (4), 475-490.

Ballantyne, D. (2004). Dialogue and its role in the development of relationship specific knowledge. Journal of Business \& Industrial Marketing. 19(2), 114-123.

Barney, J., Wright, M., \& Ketchen, D. J., Jr. (2001). The resource-based view of the firm: Ten years after 1991. Journal of Management, 27, 625-641.

Baron, R. M., \& Kenny, D.A. (1986). The Moderator-mediator variable distinction in social psychological research: Conceptual, strategic, and statistical considerations. Journal of Personality and Social Psychology, 51(6), 1173-1182.

Basadur, M., \& Gelade, G. A. (2006). The Role of Knowledge Management in the Innovation Process. Creativity and Innovation Management, 15(1), 45-62.

Bokeno, R. M. (2007). Dialogue at work? What it is and isn't. Development and Learning in Organizations: An International Journal, 21(1), 9-11.

Brown, A., \& Starkey, K. (2000). Organizational identity: A psychodynamic perspective. Academy of Management Review, 25(1), 102-120.

Brundin, E. \& Melin, L. (2011). Owners' Strategizing in the Family Firm: Dialogue as an Influential Practice. JIBS Working Papers No. 2011-15., Jönköping International Business School, Jönköping University.

Calantone, R. J., Cavusgil, S. T., \& Zhao, Y. (2002). Learning orientation, firm innovation capability, and firm performance. Industrial Marketing Management, 31, 515-524.

Callahan, J. L., \& McCollum, E. E. (2002). Conceptualizations of Emotion Research in Organizational Contexts. Advances in Developing Human Resources, 4, 4-21.

Chen, M. H. (2006). Understanding the Benefits and Detriments of Conflict on Team Creativity Process. Creativity and Innovation Management, 15(1), 105-116.

Chiva, R., \& Alegre, J. \& Lapiedra, R. (2007). Measuring organizational learning capability among the workforces. International Journal of Manpower, 28(3/4), 224-242.

Choi, T. (2014). Rational and compassionate information processing: a conceptual framework for authentic dialogue. Public Administration Review, 74(6), 726-735.

Da Camara, N., Dulewicz, V., \& Higgs, M. (2015). Exploring the relationship between perceptions of organizational emotional intelligence and turnover intentions amongst employees: the mediating role of organizational commitment and job satisfaction. Research on Emotion in Organizations, 11, 297-339.

Daftar stasiun televisi lokal di Indonesia found at Wikipedia Indonesia. https://id.wikipedia.org/wiki/Daftar_stasiun_televisi_lokal_di_Indonesia (accessed on 8 March 2020).

De Dreu, C. K. W. (2006). When Too Little or Too Much Hurts: Evidence for a Curvilinear Relationship Between Task Conflict Innovation in Teams. Journal of Management, 32, 83-103. 
DiStefano, C., \& Hess, B. (2005). Using confirmatory factor analysis for construct validation: an empirical review. Journal of Psychoeducational Assessment, 23, 225-241.

Dull, M. (2010). Leadership and Organizational Culture: Sustaining Dialogue between Practitioners and Scholars. Public Administration Review, Nov-Dec, 857-866.

Dusik, J. \& Kappiantari, M. (2010). Customizing strategic environmental assessment for Indonesian decisionmaking context: Initial lessons learnt. Accessed October 2012 at http://www.esp2indonesia.org/sites/default/files/publications/ index.aspx

Elkjaer, B. (2004). Organizational Learning: The third way. Management Learning, 35(4), 419-434.

Francis, D., \& Bessant, J. (2005). Targeting innovation and implications for capability development. Technovation, $25,171-183$.

Gallouj, F. (2002). Interactional innovation: a neo-Schumpeterian model. In J. Sundbo \& L. Fuglsang (Eds). Innovation as Strategic Reflexivity (pp. 29-56). London: Routledge.

Gebert, D., Boerner, S., \& Lanwehr, R. (2003). The Risks of Autonomy: Empirical Evidence for the Necessity of a Balance Management in Promoting Organizational Innovativeness. Creativity and Innovation Management, 12(1), 41-49.

Goleman, D. (1995). Emotional intelligence. New York: Bantam Books.

Gutíerrez-García, E. \& Recalde, M. (2016). Dialogue for strategic decision-making processes: an idea model. Advances in Public Relations and Communication Management, 1, 245-263.

Hair, J. F., Black, W. C., Babin, B. J., Anderson, R. E., \& Tatham, R. L. (2006). Multivariate Data Analysis (6th ed.). New Jersey: Pearson Education, Inc.

Harikkala-Laihinen, R., Hassett, M., Raitis, J. \& Nummela, N. (2018). Dialogue as a source of positive emotions during cross-border post-acquisition socio-cultural integration. Cross Cultural \& Strategic Management, 25(1), 183-208.

Heath, R. L., Pearce, W. B., Shotter, J., Taylor, J. R., Kersten, A., Zorn, T., Roper, J., Motion, J., \& Deetz, S. (2006). The Processes of Dialogue: Participation and Legitimation. Management Communication Quarterly, 19, 341-375.

Hofstede, G. (1997). Culture and Organisations: software of the mind. NY: McGraw-Hill Companies, Inc.

Hurley, R., \& Hult, G. T. M. (1998). Innovation, market orientation, and organizational learning: An integration and empirical examination. Journal of Marketing, 62, $42-54$.

Huy, Q. N., (1999). Emotional capability, emotional intelligence, and radical change. Academy of Management Review, 24(2), 325-345.

Huy, Q. N. (2002). Emotional balancing: The role of middle managers in radical change. Administrative Science Quarterly, 47, 31-69.

Huy, Q. N. (2012). Emotions in strategic organization: Opportunities for impactful research. Strategic Organization, 10(3), 240-247.

Isaacs, W (1993). Taking Flight: Dialogue, Collective Thinking, and Organizational Learning. Organizational Dynamics, 22(2), 24-39.

Isaacs, W. (1999). Dialogue and the Art of Thinking Together. NY: Currency.

Jabri, M. (2004). Team feedback based on dialogue: Implications for change management. Journal of Management Development, 23(2), 141-151.

Jacobs, C.D. \& Heracleous, L.T. (2005). Answers for questions to come: Reflective dialogue as an enabler of strategic innovation. Journal of Organizational Change Management, 18, 338-352.

Jehn, K.A. (1995). A multimethod examination of the benefits and detriments of intragroup conflict. Administrative Science Quarterly, 40, 256-282.

Kartodirjo, S. (1991). Modern Indonesia: Tradition and Transformation. Yogyakarta: Gajah Mada University Press.

Katrinli, A., Atabay, G., Gunay, G., Guneri, B., \& Aktan, A. (2009). Innovativeness: Is It a Function of the Leadership Style and the Value System of the Entrepreneur? In N. Aydogan (Ed). Innovation Policies, Business Creation and Economic Development (pp. 113-135). Springer Science+Business Media. 
Knekta, E., Runyon, C., \& Eddy, S. (2015). One Size Doesn't Fit All: Using Factor Analysis to Gather Validity Evidence When Using Surveys in Your Research. CBE-Life Sciences Education, 18(1), $18 \mathrm{rm} 1$. https://doi.org/10.1187/cbe.18-04-0064

Koentjaraningrat (2002). Manusia dan Kebudayaan di Indonesia, Jakarta: Djambatan.

Lam, A. (2005). Organizational Innovation. In J. Fagerberg, D.C. Mowery, \& R.R. Nelson (Eds.). The Oxford Handbook of Innovation (pp. 115-147). New York: Oxford University Press.

Li, S. (2019). The Relationship between organizational emotional capability and employee innovation behavior of S\&T enterprise. Advances in Social Science, Education and Humanities Research, 286, 37-40.

Liu, L., Chua, C., \& Stahl, G. (2010). Quality of communication experience: definition, measurement, and implications for intercultural negotiations. Journal of Applied Psychology, 95(3), 469-487.

Liu, Y. \& Phillips, J. S. (2011). Examining the antecedents of knowledge sharing in facilitating team innovativeness from a multilevel perspective. International Journal of Information Management, 31,4452.

Mackie, D. M., Devos, T., \& Smith, E. R. (2000). Intergroup Emotions: Explaining Offensive Action Tendencies in an Intergroup Context. Journal of Personality and Social Psychology, 79(4): 602-616.

McDonald, P. A. (2011). Learning from the Enemy: Identity, Conflict, and Inter-Organizational Learning. Unpublished Electronic Thesis and Dissertation Repository. The University of Western Ontario, Canada.

Menges, J. I., \& Bruch, H. (2009). Organizational emotional intelligence and performance: An empirical study. In C. E. J. Ha“rtel, N. M. Ashkanasy, \& W. J. Zerbe (Eds.), Emotions in groups, organizations and cultures, $5,181-209$.

Moldaschl, M. (2007). Institutional Reflexivity - An Institutional approach to measure innovativeness of firms. Unpublished manuscript, Working paper No. 2/2007. Department of Innovation and Sustainable Resource Management (BWL IX), Chemnitz University of Technology.

Montreuil, V., Lauzier, M., \& Gagnon, S. (2019). A closer look at determinants of organizational capability to: A dynamic capabilities perspective. European Journal of Innovation Management, Emerald Publishing Limited, 1460-1060. DOI 10.1108/EJIM-05-2019-0127.

Mulaik, S. A. (1987). A brief history of the philosophical foundations of exploratory factor analysis. Journal of Multivariate Behavioral Research, 22(3), 267-305. doi: 10.1207/s15327906mbr2203_3.

Prewitt, V. (2011). Working in the café: lessons in group dialogue. The Learning Organization, 18(3), 189-202.

Rickards, T. (2003). The Future of Innovation Research. In L. V. Shavinina (Ed.). The International Handbook of Innovation (pp. 1094-1102). Oxford: Elsevier Science Ltd.

Rose-Andersen, C. \& Allen, P. M. (2008). Diversity and learning for innovation: Dialogue for collaboration. Journal of Management Development, 27(3), 307-327.

Salavou, H. (2004). The concept of innovativeness: should we need to focus. European Journal of Innovation Management, 7(1), 33-44.

Salovey, P. \& Mayer, J. (1990). Emotional intelligence. Imagination, Cognition and Personality, 9, $185-211$.

Schein, E. H. (1992). Organizational culture and leadership (2nd ed.). San Francisco: Jossey-Bass.

Schein, E. H. (1993). On Dialogue, Culture, and Organizational Learning. Reflections, 4(4), 27-38.

Sekaran, U., \& Bougie, R. (2010). Research Methods for Business. A Skill Building Approach (5th ed.). West Sussex, UK: John Wiley \& Sons.

Senge, P. (1990). The Fifth Discipline: The Art and Practice of the Learning Organisation. London: Century.

Sundbo, J. (2002). Innovation as a strategic process. In J. Sundbo \& L. Fuglsang (Eds.). Innovation as Strategic Reflexivity (pp. 57-78). London: Routledge.

Sundbo, J. (2003). Innovation and Strategic Reflexivity: An Evolutionary Approach Applied to Services. In L. V. Shavinina (Ed.). The International Handbook on Innovation (pp. 97-114). Oxford: Elsevier Science Ltd.

Sundbo, J., \& Fuglsang, L. (2002). Innovation as strategic reflexivity. In J. Sundbo \& L. Fuglsang (Eds.). Innovation as Strategic Reflexivity (pp. 1-15). London: Routledge.

Tabachnick, B. G., \& Fidell, L. S. (2007). Using Multivariate Statistics, $5^{\text {th }}$ Ed. Boston: Pearson International Edition. 
Tricahyono, D., Nilasari, I., \& Ali, J.A. (2008, June 19). Firm Innovativeness in the context of emerging industry: the resource-based view approach. Paper presented at $I^{\text {st }}$ International Conference in Social Science and Humanities (IcoSSH), Universiti Sains Malaysia, Penang.

Ulijn, J., \& Weggeman, M. (2001). Towards an innovation culture: What are its national, corporate, marketing and engineering aspects, some experimental evidence. In C. L. Cooper, S. Cartwright, \& P. C. Earley (Eds.), The international handbook of organizational culture and climate (p. 487-517). New York, NY: Wiley.

Von Koskull, C. Strandvik, T. \& Tronvoll, B. (2016). Emotional strategizing in service innovation. Management Decision, 54(2), 270-287. DOI 10.1108/MD-06-2014-0339.

Walker, J., \& Ferguson, D. (1998). The Broadcast Television Industry. Boston: Allyn \& Bacon.

Wang, C.L., \& Ahmed, P.K. (2004). The development and validation of the organizational innovativeness construct using confirmatory factor analysis. European Journal of Innovation Management, 7(4), 303-313.

Yeung, A. K., Ulrich, D. O., Nason, S. W., \& Von Glinow, M. A. (1999). Organizational Learning Capability. New York: Oxford University Press.

Yip, J. A., \& Martin, R. A. (2006). Sense of humour, emotional intelligence, and social competence. Journal of Research in Personality, 40, 1202-1208.

Yousaf, S., Anser, M. K., Tariq, M., Jawad, S. U. R. S. S., Naushad, S., \& Yousaf, Z. (2020). Does technology orientation predict firm performance through firm innovativeness? World Journal of Entrepreneurship, Management and Sustainable Development, Emerald Publishing Limited, 2042-5961. DOI 10.1108/WJEMSD-11-2019-0091. 